\title{
Data report: consolidation properties of silty claystones and sandstones sampled seaward of the Nankai Trough subduction zone, IODP Sites C0011 and C0012 ${ }^{1}$
}

\author{
Andre Hüpers ${ }^{2}$ and Achim J. Kopf ${ }^{2}$
}

\begin{abstract}
Chapter contents

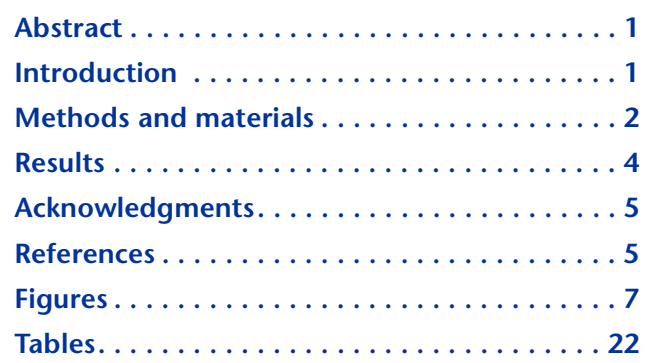

${ }^{1}$ Hüpers, A., and Kopf, A.J., 2012. Data report: consolidation properties of silty claystones and sandstones sampled seaward of the Nankai Trough subduction zone, IODP Sites C0011 and C0012. In Saito, S., Underwood, M.B., Kubo, Y., and the Expedition 322 Scientists, Proc. IODP, 322: Tokyo (Integrated Ocean Drilling Program Management International, Inc.).

doi:10.2204/iodp.proc.322.203.2012

2MARUM-Center for Marine Environmental Sciences, Leobener Strasse MARUM, 28359 Bremen, Germany. Correspondence author: andre.huepers@uni-bremen.de

\begin{abstract}
We conducted incremental loading and constant rate of strain consolidation tests on sediments recovered during Integrated Ocean Drilling Program (IODP) Expedition 322 from Sites C0011 and C0012, located seaward of the deformation front in the Nankai Trough subduction zone, southeast Japan. In total, five silty claystones and six sandstone samples from lithologic Units II-V were tested. The results document higher compressibilities for clay-rich specimens with compression indexes of $C_{\mathrm{c}}=0.4829-$ 0.6905 , whereas sandstones are characterized by values of $C_{c}=$ $0.2257-0.4357$.

Maximum past effective stresses of silty claystones from Units II and III suggest a normal to slightly overconsolidated state. Samples from Units IV and V are significantly overconsolidated with overconsolidation ratios of 2.06-2.51. Vertical effective stresses of $\sim 10 \mathrm{MPa}$ are needed to force yielding nonvolcanic sandstones. These yield stresses are significantly higher than the calculated value of in situ hydrostatic vertical effective stresses. In contrast, volcanic sandstones yield at stresses close to the in situ hydrostatic effective stress.

For all tested specimens, the logarithm of hydraulic conductivity $K$ shows a linear relationship with void ratio, with sandstones exhibiting higher $K$ values. Calculated in situ intrinsic permeabilities for silty claystones decrease with depth from $1.8 \times 10^{-17} \mathrm{~m}^{2}$ at $377.81 \mathrm{~m}$ core depth below seafloor (CSF) to $8.5 \times 10^{-20} \mathrm{~m}^{2}$ at $749.38 \mathrm{~m}$ CSF. In situ intrinsic permeabilities of sandstones do not show a clear trend but scatter between values of $1.3 \times 10^{-15}$ and $4.0 \times 10^{-17} \mathrm{~m}^{2}$.
\end{abstract}

\section{Introduction}

The Nankai Trough Seismogenic Zone Experiment (NanTroSEIZE) is a multistage, multiplatform drilling project within the Integrated Ocean Drilling Program (IODP) designed to shed light on fault mechanics and controls on seismogenesis along the Nankai Trough subduction megathrust (Tobin and Kinoshita, 2006). The project includes in situ measurements, long-term monitoring, and direct sampling of sediments and crustal rocks from the Nankai Trough subduction zone complex offshore the Kii Peninsula, southeast Japan (Fig. F1). 
During the NanTroSEIZE project's second stage, the sediments approaching the subduction zone were penetrated during IODP Expedition 322 approximately $15 \mathrm{~km}$ seaward of the trench. The purpose of this expedition within the project's framework was to sample sediments, fluids, and basement rocks and to serve as reference sites for boreholes in the accretionary complex (see the "Expedition 322 summary" chapter [Underwood et al., 2010]). In 2009, Expedition 322 drilled two sites with the D/V Chikyu that were selected for their contrasting seafloor relief. The sites are on the northwest flank (Site C0011) and on the crest (Site C0012) of the Kashinosaki Knoll (Fig. F1). Five distinct sedimentary units were penetrated with well-correlated unit boundaries between the two sites (see the "Site C0011" and "Site C0012" chapters [Expedition 322 Scientists, 2010a, 2010b]) (Fig. F2). Visual core description documented predominantly silty claystone of Quaternary to middle Miocene age, but numerous sandstone interbeds were sampled in Units II (volcanic turbidite facies), IV (silty turbidite facies), and V (volcaniclastic-rich facies).

In the present study, we focus on geotechnical testing of recovered sediment samples with differences in lithology, which may exert fundamental control over compressibility, fluid flow, and excess pore pressures (Saffer et al., 2011). To predict these parameters in the subduction zone, it is vital to account for lithologic heterogeneity in consolidation behavior and hydrologic properties. To investigate the role of lithology, we tested five samples of silty claystone and six samples of sandstone from Sites C0011 and C0012 from lithologic Units II-V of the subduction inputs (Table T1). Incremental loading and constant rate of strain (CRS) consolidation tests were conducted on intact and remolded samples to determine maximum past effective stress and in situ intrinsic permeability as well as compressibility and hydraulic conductivity during uniaxial deformation. NanTroSEIZE-related studies that focus on coupled fluid flow and sediment deformation would benefit from these measurements, which describe a lithologically diverse section of sediment inputs.

\section{Methods and materials}

\section{Sampling and sample handling}

Sampling of whole-round cores during Expedition 322 was conducted after partitioning the recovered core into $1.5 \mathrm{~m}$ length sections and temperature equilibration for multisensor core logging. Sample intervals of $10-20 \mathrm{~cm}$ of undisturbed silty claystones suitable for geotechnical testing were identified by
X-ray computed tomography. The selected sample intervals were cut and sealed in the core liner and packed in aluminum vacuum bags. Samples of sandy sediments were taken from the working halves, with exception of Sample 322-C0012A-45R-4, 79-95 cm (Table T1). Selected specimens were put in a bisected core liner, wrapped in plastic film, and sealed in an aluminum vacuum bag. During storage and transport, all samples were kept refrigerated at $\sim 4^{\circ} \mathrm{C}$ until used for laboratory testing.

\section{Incremental loading consolidation tests}

Incremental loading consolidation tests were conducted on all silty claystone and sandstone samples with a fixed-ring oedometer in the Center for Marine Environmental Sciences (MARUM) geotechnical laboratory at the University of Bremen. The oedometer ring that confines the sample is fixed to the bottom of an open cell filled with artificial seawater to which the pore water in the sample has free access. The ring has an inner diameter of $25.40 \mathrm{~mm}$ (area $=5 \mathrm{~cm}^{2}$ ) and a height of $14.75 \mathrm{~mm}$. The small ring size was necessary to prepare intact samples extracted from half rounds parallel to the longitudinal axis of the core. All samples were carefully trimmed with a knife to fit exactly into the ring. Because of the presence of microcracks (possibly drilling induced), sample height varied between 10.56 and $14.75 \mathrm{~mm}$, and no intact specimen could be prepared from Sample 322C0011B-28R-1, 0-17 cm. This sample was remolded for the consolidation test.

For the consolidation experiments we used two loading frames with maximum vertical stress capacities of 16 and $20 \mathrm{MPa}$ for an area of $5 \mathrm{~cm}^{2}$. Stress is applied to both frames with weights on a lever arm. At the beginning of each experiment, the specimen was saturated with artificial seawater (35\%o salinity) in the oedometer cell for $24 \mathrm{~h}$ with applied vertical stresses $\left(\sigma_{v}\right)$ of $0.01-0.06 \mathrm{MPa}$. For the loading phase of the consolidation test, the applied vertical stress is doubled until the maximum capability of the respective loading frame was reached. Each load step was maintained for $24 \mathrm{~h}$ to allow complete pore pressure dissipation such that the applied vertical stress is equal to the vertical effective stress $\left(\sigma_{\mathrm{v}}^{\prime}\right)$. For the unloading phase, we reduced the applied vertical stress by $\sim 75 \%$ every $24 \mathrm{~h}$. During the experiment, the time $(t)$, the applied vertical stress $\left(\sigma_{v}\right)$, and the relative displacement $h$ (accuracy $= \pm 0.01 \mathrm{~mm}$ ) were recorded. After the experiment, the final sample height was measured with a caliper (accuracy $= \pm 0.01$ $\mathrm{mm})$. The final void ratio $e_{\text {end }}$ is calculated by

$$
e_{\text {end }}=V_{\mathrm{w}} /\left(V_{\mathrm{b}}-V_{\mathrm{w}}\right) \text {, }
$$


where $V_{\mathrm{w}}$ is the volume of pore water (in $\mathrm{cm}^{3}$ ) and $V_{\mathrm{b}}$ is the bulk volume of the compacted specimen after the test (in $\left.\mathrm{cm}^{3}\right) . V_{\mathrm{b}}$ is given by the height of the sample and the ring area $\left(5 \mathrm{~cm}^{2}\right)$, and $V_{\mathrm{w}}$ is determined following Blum (1997) by oven drying the sample for $24 \mathrm{~h}$ at $105^{\circ} \mathrm{C}$. The change of void ratio during the consolidation test was calculated using the displacement data with the final void ratio as reference.

Plots of consolidation data from incremental loading tests show void ratio $e$ at the end of loads steps when $\sigma_{v}=\sigma_{v}^{\prime}$ against the logarithm of the vertical effective stress $\left(\sigma_{v}^{\prime}\right)$. The compressibility characteristics of the samples are reported as compression indexes. The compression index is the slope of a linear portion in the plot given by

$$
\text { compression index }=\Delta e / \Delta \log \left(\sigma_{\mathrm{v}}^{\prime}\right) .
$$

A preconsolidated sample undergoes a recompression phase, a primary consolidation phase, and an unloading phase. For the different phases of the consolidation test, we determined the recompression index $\left(C_{\mathrm{r}}\right)$, the compression index $\left(C_{\mathrm{c}}\right)$ and the expansion index $\left(C_{\mathrm{e}}\right)$, respectively.

Consolidation test data also allow estimation of the maximum past effective stress $\left(P^{\prime}{ }_{c}\right)$ experienced by a clay-rich sediment. In the present study, we used the Casagrande method to estimate the value of $P^{\prime}{ }_{c}$ (Casagrande, 1936). In this method, the value of $P^{\prime}{ }_{c}$ is obtained from the intersection between the backward projected line of primary consolidation and the bisecting line between the horizontal and tangent line at the point of maximum curvature of the consolidation curve. Because of low data resolution of incremental loading consolidation tests, we interpolated consolidation data on the basis of a rational equation fit. The point of maximum curvature of the fit was computed using a second-order numerical solution following Dawidowski and Koolen (1994).

The consolidation state of the samples is defined by the ratio of $P^{\prime}{ }_{c}$ to the in situ vertical hydrostatic effective stress $\sigma^{\prime}{ }_{v h}$. This is known as the overconsolidation ratio (OCR) and defined as $P^{\prime}{ }_{c} / \sigma^{\prime}{ }_{\text {vh }}$. The vertical hydrostatic effective stress corresponds to the stress at depth assuming that only hydrostatic pore pressure exists in the sediment and is calculated by integrating the sediment's bulk density from shipboard measurements upward from the sample depth to the seafloor combining Expedition 322 and 333 data (see the "Expedition 322 summary" chapter [Underwood et al., 2010]; Expedition 333 Scientists, 2011). $\sigma^{\prime}{ }_{v h}$ is approximated by

$$
\sigma_{\mathrm{vh}}^{\prime}=\mathrm{g} \times \Sigma\left(\rho_{\mathrm{b}}-\rho_{\mathrm{w}}\right) \times \Delta z
$$

where

$$
\begin{aligned}
& \mathrm{g}=\text { gravity acceleration }\left(9.81 \mathrm{~m} / \mathrm{s}^{2}\right), \\
& \rho_{\mathrm{b}}=\text { bulk density }\left(\mathrm{kg} / \mathrm{m}^{3}\right) \text { of the depth interval, } \\
& \rho_{\mathrm{w}}=\text { pore water density }\left(1025 \mathrm{~kg} / \mathrm{m}^{3}\right), \text { and } \\
& \Delta z=\text { depth interval }(\mathrm{m}) .
\end{aligned}
$$

If the maximum past effective stress $P^{\prime}{ }_{c}$ is equal to $\sigma^{\prime}{ }_{v h}(\mathrm{OCR}=1)$, the tested sample is considered to be normally consolidated. For OCR $<1$, the consolidation state is referred to underconsolidated, and in the inverse case the sample is overconsolidated.

Yielding of sandstones does not reflect the maximum past effective stress and may have other causes (e.g., Karig and Hou, 1992). Nonetheless, we applied the same analysis as for the silty claystones and keep also the nomenclature. Thus, we determined compression indexes, employed the Casagrande (1936) method to estimate the yieldpoint at which a rapid increase in compressibility occurs, and related the yieldpoint to the in situ vertical hydrostatic stress to obtain OCR.

As part of the consolidation analysis, the hydraulic conductivity $K(\mathrm{~m} / \mathrm{s})$ was computed by

$$
K=C_{\mathrm{v}} \times m_{\mathrm{v}} \times \gamma_{\mathrm{w}} .
$$

$C_{\mathrm{v}}$ is the coefficient of consolidation $\left(\mathrm{m}^{2} / \mathrm{s}\right)$ and is determined for each load step using the Taylor method as described in Craig (2004). $\gamma_{w}$ denotes the unit weight of the pore water $\left(\mathrm{kg} /\left[\mathrm{m}^{2} \times \mathrm{s}^{2}\right]\right)$, and $m_{\mathrm{v}}$ is the coefficient of volume compressibility $\left(\mathrm{m}^{2} / \mathrm{MN}\right)$, calculated by

$$
m_{\mathrm{v}}=\left[1 /\left(1+e_{0}\right)\right] \times\left[\left(e_{0}-e_{1}\right) /\left(\sigma_{\mathrm{v} 1}^{\prime}-\sigma_{\mathrm{v} 0}^{\prime}\right)\right],
$$

where

$$
\begin{aligned}
e_{0}= & \text { void ratio at the beginning of the load step, } \\
e_{1}= & \text { void ratio at the end of the load step, } \\
\sigma_{\mathrm{v} 1}^{\prime}= & \text { vertical effective stress of the previous load } \\
& \text { step, and } \\
\sigma_{\mathrm{v} 0}^{\prime}= & \text { vertical effective stress of the actual load } \\
& \text { step. }
\end{aligned}
$$

The logarithm of the obtained hydraulic conductivity is presented as a function of void ratio for each sample (Fig. F3) and fitted with a relation of

$$
\log (K)=\alpha \times e+\log \left(K_{0}\right),
$$

where $\alpha$ is the change of hydraulic conductivity with void ratio and $\log \left(K_{0}\right)$ is the projected value at zero void ratio. 
Hydraulic conductivity is a function of fluid properties, which may be different for laboratory and in situ conditions. Therefore, it is convenient to convert $K$ into intrinsic permeability, which is a function of the porous medium alone (Fetter, 2001). The relation between hydraulic conductivity and the intrinsic permeability is

$$
k=(K \times v) / \gamma_{w}
$$

where $v$ is the dynamic fluid viscosity of water at $20^{\circ} \mathrm{C}$ (0.001 Pa.s) (Fetter, 2001).

We assume that the void ratio at the laboratory-determined maximum past effective stress $\left(P_{c}^{\prime}\right)$ represents the in situ void ratio $e_{P^{\prime} c}$ (Dugan and Daigle, 2011). To determine the in situ intrinsic permeability, we combine the fitted relation between void ratio and hydraulic conductivity with the conversion from hydraulic conductivity into intrinsic permeability $k\left(\mathrm{~m}^{2}\right)$ such that the in situ intrinsic permeability $k_{\mathrm{i}}$ can be estimated by

$$
k_{\mathrm{i}}=10^{\left[\left(\mathrm{a} \times e_{\mathrm{P}^{\prime} \mathrm{C}}\right)+\log \left(K_{0}\right)\right]} \times\left(\mathrm{v} / \gamma_{\mathrm{w}}\right) \text {. }
$$

The in situ intrinsic permeability $k_{\mathrm{i}}$ of sandstones was also determined for void ratios that correspond to the maximum past effective stress in incremental loading tests.

\section{Constant rate of strain consolidation tests}

Insufficient resolution of incremental loading test data prevented the calculation of $C_{\mathrm{v}}$ and $K$ for intact sandstone samples. Therefore, we conducted CRS tests on remolded samples in addition to the incremental loading consolidation tests on intact samples to determine the $e-\log (K)$ relation. Void ratios from incremental loading tests are put into the best fit equation to calculate the associated $K$ for intact samples. Together with the calculated $m_{v}$ from the incremental loading tests, $C_{\mathrm{v}}$ is computed by

$$
C_{\mathrm{v}}=\left(m_{\mathrm{v}} \times \gamma_{\mathrm{w}}\right) / K
$$

We used a custom-made CRS cell with a diameter of $63 \mathrm{~mm}$ in combination with a computer-controlled hydraulically driven load frame (Fig. F4). The larger diameter of the cell made it necessary to remold the samples. Samples were disaggregated by careful crushing of the specimen with a flexible spatula and simultaneous addition of artificial seawater until a void ratio of $\sim 1$ was achieved. The height of the sample varied between 21.84 and $9.96 \mathrm{~mm}$ depending on available sample material. The sample was confined by the stainless steel cell wall, which ensures only uniaxial strain. The sample was allowed to drain upward, with atmospheric pressure at the top while the base is sealed. Vertical stresses of up to $\sim 70-80 \mathrm{MPa}$ were applied at strain rates up to $22 \% / \mathrm{h}$ to induce a sufficient basal pore pressure in the specimen. We neglected the holding phase at maximum applied stress because compression behavior was already determined from incremental loading tests. The time $(t)$, applied vertical stress $\left(\sigma_{\mathrm{v}}\right)$, excess pore water pressure at the base $(\Delta u)$, and the relative displacement (accuracy $\pm 0.01 \mathrm{~mm}$ ) were recorded during deformation. After the experiment the sample height and the final void ratio were determined in the same way as the postsample handling of incremental loading tests. We computed vertical effective stress $\sigma^{\prime}{ }_{v}$ and hydraulic conductivity $K$ according to American Society for Testing and Materials (ASTM) Standard D854-06 (ASTM, 2006) with

$$
\begin{gathered}
\sigma^{\prime}{ }_{v}=\sigma_{v}-2 / 3 \times \Delta u \text { and } \\
K=\left(\dot{\varepsilon} \times h_{\mathrm{n}} \times h_{0} \times \gamma_{\mathrm{w}}\right) /(2 \times \Delta u),
\end{gathered}
$$

where

$$
\begin{aligned}
h_{\mathrm{n}}= & \text { sample height at time } t_{\mathrm{n}} \text { during the experi- } \\
& \text { ment, } \\
h_{0}= & \text { initial sample height at starting time } t_{0} \text {, and } \\
\dot{\varepsilon}= & \text { strain rate. }
\end{aligned}
$$

The strain rate is calculated by

$$
\dot{\varepsilon}=\left[\left(h_{0}-h_{\mathrm{n}}\right) / h_{0}\right] /\left(t_{\mathrm{n}}-t_{0}\right) .
$$

The logarithm of hydraulic conductivity is presented as a function of void ratio. Curve fitting was performed similar to incremental loading tests, again using the following linear relation:

$$
\log (K)=\alpha \times e+\log \left(K_{0}\right) .
$$

\section{Results}

All consolidation data are plotted in Figures F3, F5, F6, F7, F8, F9, F10, F11, F12, F13, and F14 together with best fit regression lines of compression indexes, maximum past effective stress constructions, and hydraulic conductivities as a function of void ratio. The equations of the fitted regression lines of compression indexes are presented in Table T2. Computed in situ vertical hydrostatic effective stresses, maximum past effective stresses, OCRs, in situ void ratios, regression equations for hydraulic conductivities, and in situ intrinsic permeabilities are presented for silty claystones (Table T3) and sandstones (Table T4) separately. All nomenclature is provided in Table T5. Data of all consolidation experiments are also avail- 
able as supplementary material (see CONSOL in "Supplementary material").

The consolidation properties document a significant difference between silty claystone and sandstone samples: clay-rich lithologies have higher compressibilities and lower in situ intrinsic permeabilities (Fig. F15). Recompression indexes of claystones range from 0.0222 to 0.0557 , and compression indexes range from 0.4829 to 0.6905 . Elastic compression is twice as high as recompression indexes, with values of $0.0663-0.1338$. Maximum past effective stresses suggest that samples from lithologic Units II and III are slightly overconsolidated with OCRs of 1.22-1.23. In contrast, samples from Units IV and V are significantly overconsolidated with OCRs values of 2.06 and 2.51, respectively. Calculated hydraulic conductivity data from consolidation tests reveal a log-linear decrease as a function of void ratio. Void ratios of intact samples are at low stresses between 0.8132 and 1.11593 and decrease to $0.5983-0.4599$ throughout the tests. Associated hydraulic conductivities are from $3.4 \times 10^{-9}$ to $7.5 \times 10^{-11} \mathrm{~m} / \mathrm{s}$ and from $2.0 \times 10^{-13}$ to $6.3 \times 10^{-14} \mathrm{~m} / \mathrm{s}$, respectively. In situ intrinsic permeabilities decrease with depth from $1.8 \times 10^{-17} \mathrm{~m}^{2}$ at $377.81 \mathrm{~m} \mathrm{CSF}$ to $8.5 \times 10^{-20} \mathrm{~m}^{2}$ at $749.38 \mathrm{~m} \mathrm{CSF}$, consistent with a decreasing in situ void ratio with depth.

Compression indexes show less variability for sandrich samples. Recompression indexes are generally small with values of $0.0245-0.0058$, which are consistent with the elastic compression indexes. Compression indexes for primary consolidation are from 0.2257 to 0.4357 , with the exception of Sample 322C0011B-8R-3, 104-115 cm. Consolidation data for this sample are characterized by extremely high void ratios, which point to an erroneous data set. Yield stresses are high for all nonvolcanic sandstones, with values scattered between 6.91 and $12.61 \mathrm{MPa}$ and associated OCRs varying between 1.85 and 3.61. The volcanic sandstones from Unit II yield at effective stresses of 2.21 to $3.35 \mathrm{MPa}$, which correspond to OCRs of 0.85 and 1.30 , respectively.

Hydraulic conductivities computed from CRS tests for remolded sandstones follow a log-linear decrease with void ratio. Compared to the clay-rich samples, the $\log (K)$-e functions of sandstone specimens show a similar change with void ratio but an offset in $\log \left(K_{0}\right)$ toward higher conductivities. Void ratios of intact sandstone samples have values of 1.61490.6712 at low stresses and void ratios of 0.8359 0.5256 at maximum applied stresses. Associated hydraulic conductivities have values of $1.3 \times 10^{-7}$ to 1.0 $\times 10^{-9} \mathrm{~m} / \mathrm{s}$ and $3.8 \times 10^{-9}$ to $5.8 \times 10^{-11} \mathrm{~m} / \mathrm{s}$, respec- tively. In situ intrinsic permeabilities scatter between $4.0 \times 10^{-17}$ and $1.3 \times 10^{-15} \mathrm{~m}^{2}$.

\section{Acknowledgments}

This work used samples provided by the Integrated Ocean Drilling Program (IODP). We thank the crew and laboratory technicians onboard the D/V Chikyu and the shipboard scientists of IODP Expedition 322 for their excellent support. Funding was provided to A. Hüpers by the German Science Foundation (DFG project HU 1789/1-1). We thank Junhua Guo and Mike Underwood for their constructive reviews.

\section{References}

ASTM International, 2006. Standard test method for onedimensional consolidation properties of saturated cohesive soils using controlled-strain loading (Standard D4186-06). In Annual Book of ASTM Standards (Vol. 04.08): Soil and Rock (I): West Conshohocken, PA (Am. Soc. Testing Mater.)

Blum, P., 1997. Physical properties handbook: a guide to the shipboard measurement of physical properties of deep-sea cores. ODP Tech. Note, 26. doi:10.2973/ odp.tn.26.1997

Casagrande, A., 1936. The determination of pre-consolidation load and its practical significance. In Casagrande, A., Rutledge, P.C., and Watson, J.D. (Eds.), Proc. 1st Int. Conf. Soil Mech. Found. Eng. Am. Soc. Civ. Eng., 3:60-64.

Craig, R.F., 2004. Craig's Soil Mechanics (7th ed.): London (Taylor \& Francis).

Dawidowski, J.B., and Koolen, A.J., 1994. Computerized determination of the preconsolidation stress in compaction testing of field core samples. Soil Tillage Res., 31(23):277-282. doi:10.1016/0167-1987(94)90086-8

Dugan, B., and Daigle, H., 2011. Data report: permeability, compressibility, stress state, and grain size of shallow sediments from Sites C0004, C0006, C0007, and C0008 of the Nankai accretionary complex. In Kinoshita, M., Tobin, H., Ashi, J., Kimura, G., Lallemant, S., Screaton, E.J., Curewitz, D., Masago, H., Moe, K.T., and the Expedition 314/315/316 Scientists, Proc. IODP, 314/315/316: Tokyo (Integrated Ocean Drilling Program Management International, Inc.). doi:10.2204/

iodp.proc.314315316.208.2011

Expedition 322 Scientists, 2010a. Site C0011. In Saito, S., Underwood, M.B., Kubo, Y., and the Expedition 322 Scientists, Proc. IODP, 322: Tokyo (Integrated Ocean Drilling Program Management International, Inc.). doi:10.2204/iodp.proc.322.103.2010

Expedition 322 Scientists, 2010b. Site C0012. In Saito, S., Underwood, M.B., Kubo, Y., and the Expedition 322 Scientists, Proc. IODP, 322: Tokyo (Integrated Ocean Drilling Program Management International, Inc.). doi:10.2204/iodp.proc.322.104.2010 
Expedition 333 Scientists, 2011. NanTroSEIZE Stage 2: subduction inputs 2 and heat flow. IODP Prel. Rept., 333. doi:10.2204/iodp.pr.333.2011

Fetter, C.W., 2001. Applied Hydrogeology (4th ed.): Upper Saddle River, NJ (Prentice Hall).

Karig, D.E., and Hou, G., 1992. High-stress consolidation experiments and their geologic implications. J. Geophys. Res., [Solid Earth], 97(B1):289-300. doi:10.1029/ 91JB02247

Saffer, D., Guo, J., Underwood, M.B., Likos, W., Skarbek, R.M., Song, I., and Gildow, M., 2011. Data report: consolidation, permeability, and fabric of sediments from the Nankai continental slope, IODP Sites C0001, C0008, and C0004. In Kinoshita, M., Tobin, H., Ashi, J., Kimura, G., Lallemant, S., Screaton, E.J., Curewitz, D., Masago, H., Moe, K.T., and the Expedition 314/315/316 Scientists, Proc. IODP, 314/315/316: Washington, DC (Inte- grated Ocean Drilling Program Management International, Inc.). doi:10.2204/ iodp.proc.314315316.218.2011

Tobin, H.J., and Kinoshita, M., 2006. NanTroSEIZE: The IODP Nankai Trough Seismogenic Zone Experiment. Sci. Drill., 2: 23-27. doi:10.2204/iodp.sd.2.06.2006

Underwood, M.B., Saito, S., Kubo, Y., and the Expedition 322 Scientists, 2010. Expedition 322 summary. In Saito, S., Underwood, M.B., Kubo, Y., and the Expedition 322 Scientists, Proc. IODP, 322: Tokyo (Integrated Ocean Drilling Program Management International, Inc.). doi:10.2204/iodp.proc.322.101.2010

Initial receipt: 13 September 2011

Acceptance: 11 July 2012

Publication: 10 October 2012

MS 322-203 
Figure F1. Bathymetric map with drilling locations of the NanTroSEIZE project offshore Kii peninsula (from the "Expedition 322 summary" chapter [Underwood et al., 2010]). Sites C0011 and C0012 are $\sim 15 \mathrm{~km}$ seaward of the deformation front of the Nankai Trough subduction zone complex. Site C0011 is on the northern flank of Kashinosaki Knoll, and Site C0012 is on its crest. Yellow arrows show direction and velocity of Philippine Sea plate movement.

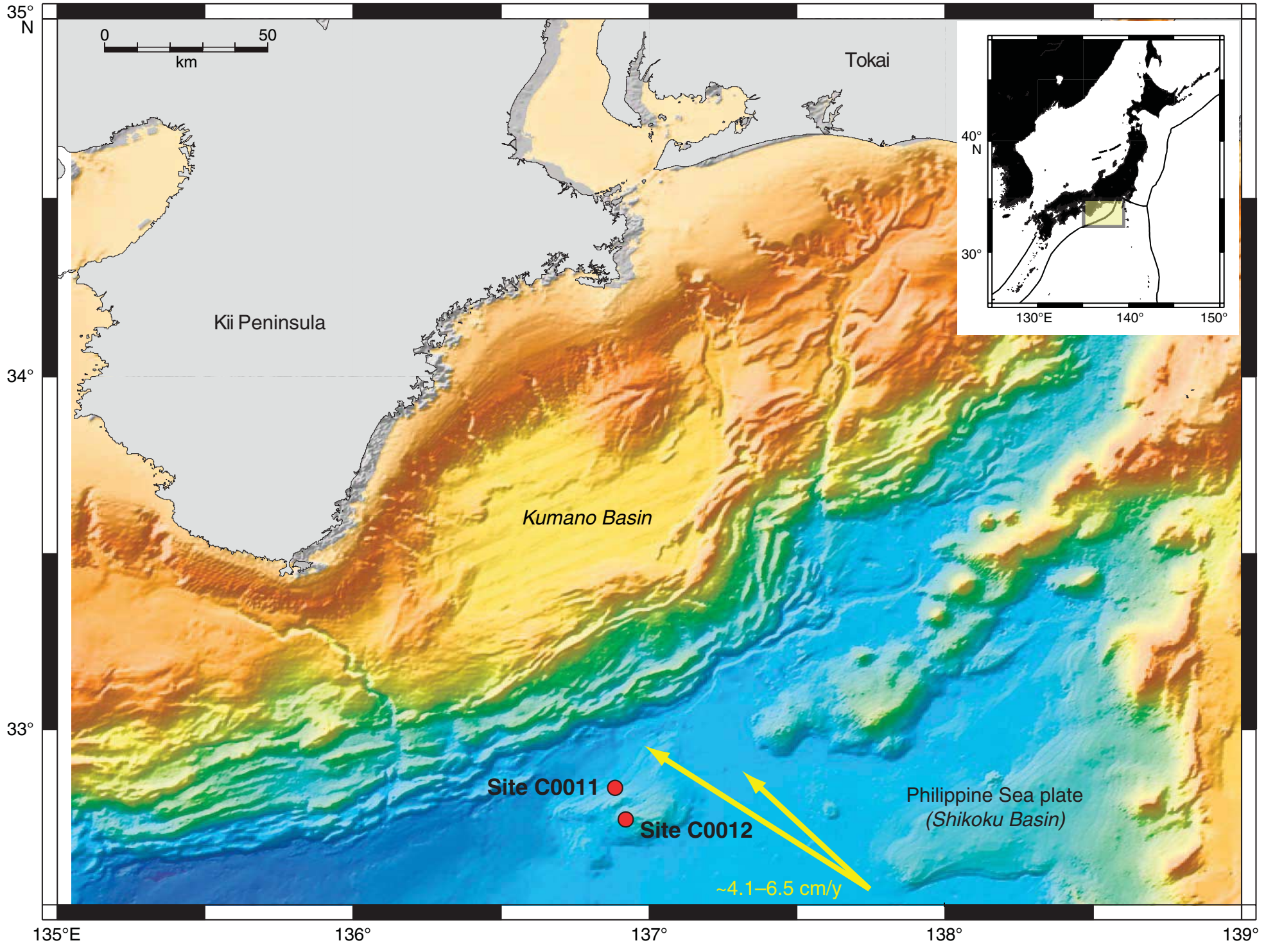


Figure F2. Diagram of lithologic units at Sites C0011 and C0012 (after the "Expedition 322 summary" chapter [Underwood et al., 2010]). Coring started at Site C0011 at $340 \mathrm{~m}$ CSF. The hole was abandoned at $876 \mathrm{~m}$ CSF. Coring at Site C0012 started at $60 \mathrm{~m} \mathrm{CSF}$ and continued to a total depth of $576 \mathrm{~m}$ CSF. Sediment specimens (X) were recovered from Units II-IV at Site C0011 and Unit V at Site C0012.

Hole C0011B

Hole C0012A

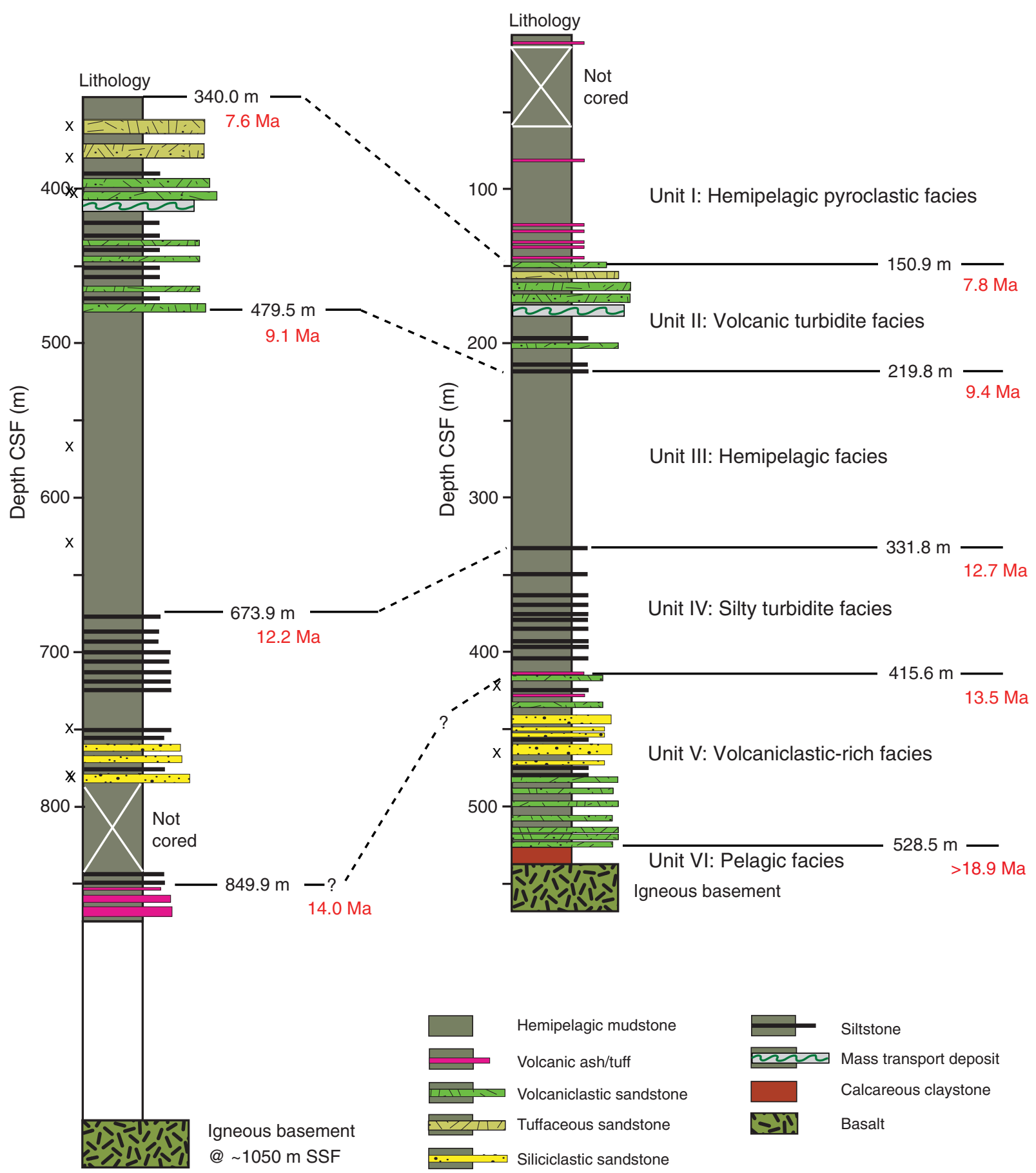


Figure F3. Plots of experimental results from Sample 322-C0011B-3R-3, 53-63 cm (lithologic Unit II; $360.71 \mathrm{~m}$ CSF; tuffaceous sandstone). A. Data from incremental loading consolidation test (IC) conducted on intact sample with regression lines for recompression (blue), primary compression (red), and elastic compression (green). B. Maximum past effective stress $P^{\prime}{ }_{c}$ with Casagrande construction and in situ hydrostatic vertical effective stress $\sigma_{v h}^{\prime}$. C. Logarithm of hydraulic conductivity as a function of void ratio determined from constant rate of strain consolidation test (CRS) conducted on remolded sample.
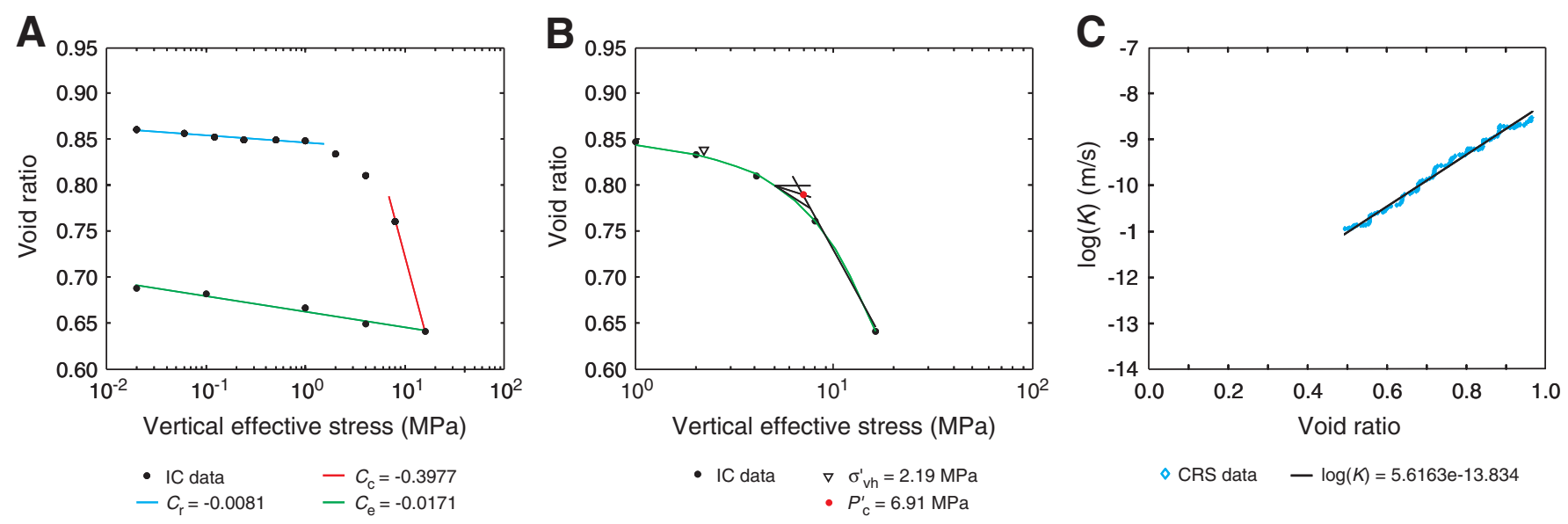
Figure F4. Schematic cross-section of the consolidation cell used for constant rate of strain tests on Site C0011 and C0012 samples. The (A) sample is consolidated between (B) upper and (C) lower pistons. The (D) cell wall prevents the sample from lateral extension. Pore water pressure is measured by a (E) pressure transducer attached to the lower piston. During the experiment, the sample is allowed to drain through the (F) upper pore water outlet.

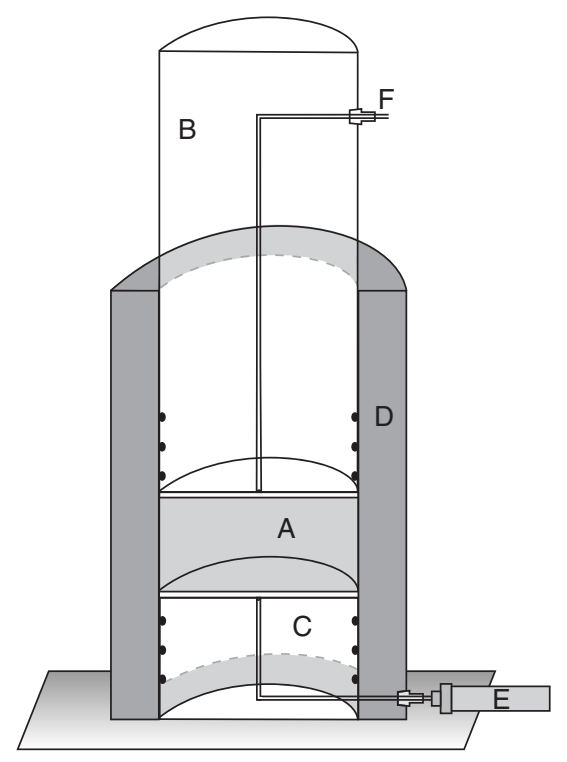


Figure F5. Plots of experimental results from Sample 322-C0011B-5R-4, 85-105 cm (lithologic Unit II; 377.81 m CSF; silty claystone). A. Data from incremental loading consolidation test (IC) conducted on intact sample with regression lines for recompression (blue), primary compression (red), and elastic compression (green). B. Maximum past effective stress $P^{\prime}{ }_{c}$ with Casagrande construction and in situ hydrostatic vertical effective stress $\sigma_{\mathrm{vh}}^{\prime}$. C. Logarithm of hydraulic conductivity as a function of void ratio determined from IC.
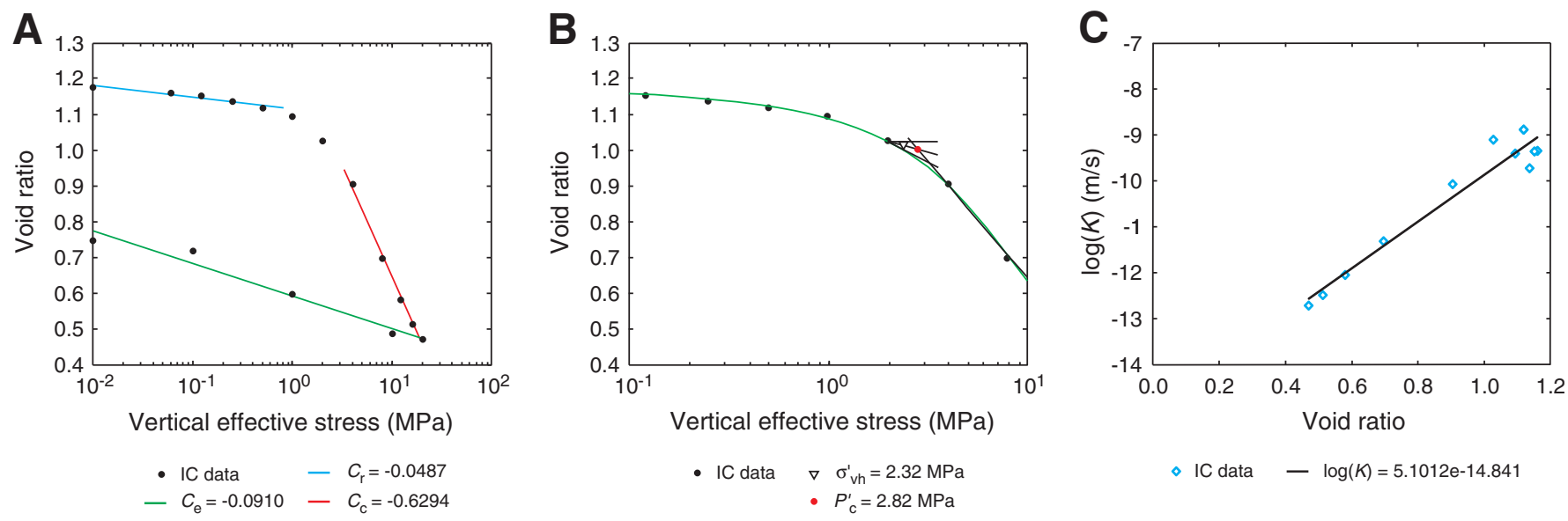

$\begin{array}{ll}\text { IC data } & -C_{\mathrm{r}}=-0.0487 \\ -C_{\mathrm{e}}=-0.0910-C_{\mathrm{c}}=-0.6294\end{array}$ 
Figure F6. Plots of experimental results from Sample 322-C0011B-8R-3, 104-115 cm (lithologic Unit II; 405.63 $\mathrm{m}$ CSF; volcanic sandstone). A. Data from incremental loading consolidation test (IC) conducted on intact sample with regression lines for recompression (blue), primary compression (red), and elastic compression (green). B. Maximum past effective stress $P^{\prime}{ }_{c}$ with Casagrande construction and in situ hydrostatic vertical effective stress $\sigma^{\prime}{ }_{v h}$. C. Logarithm of hydraulic conductivity as a function of void ratio determined from constant rate of strain consolidation test (CRS) conducted on remolded sample.
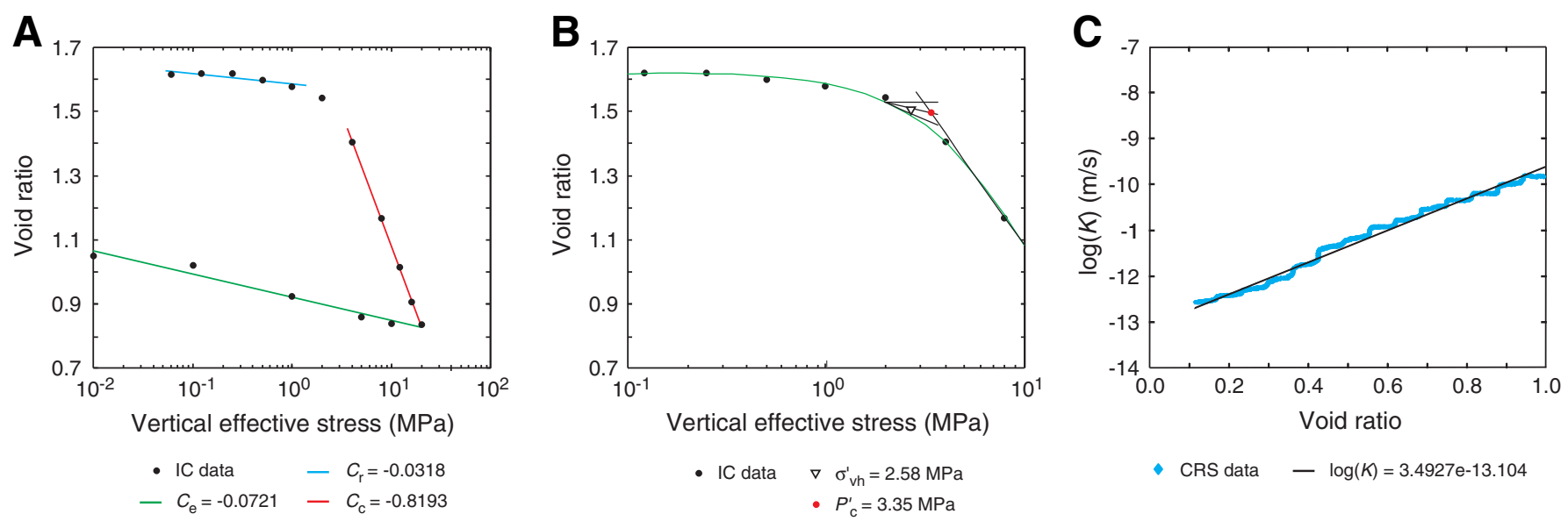
Figure F7. Plots of experimental results from Sample 322-C0011B-8R-4, 49-61 cm (lithologic Unit II; $406.49 \mathrm{~m}$ CSF; volcanic sandstone). A. Data from incremental loading consolidation test (IC) conducted on intact sample with regression lines for recompression (blue), primary compression (red), and elastic compression (green). B. Maximum past effective stress $P^{\prime}{ }_{c}$ with Casagrande construction and in situ hydrostatic vertical effective stress $\sigma_{\text {vh. }}^{\prime}$. C. Logarithm of hydraulic conductivity as a function of void ratio determined from constant rate of strain consolidation test (CRS) conducted on remolded sample.
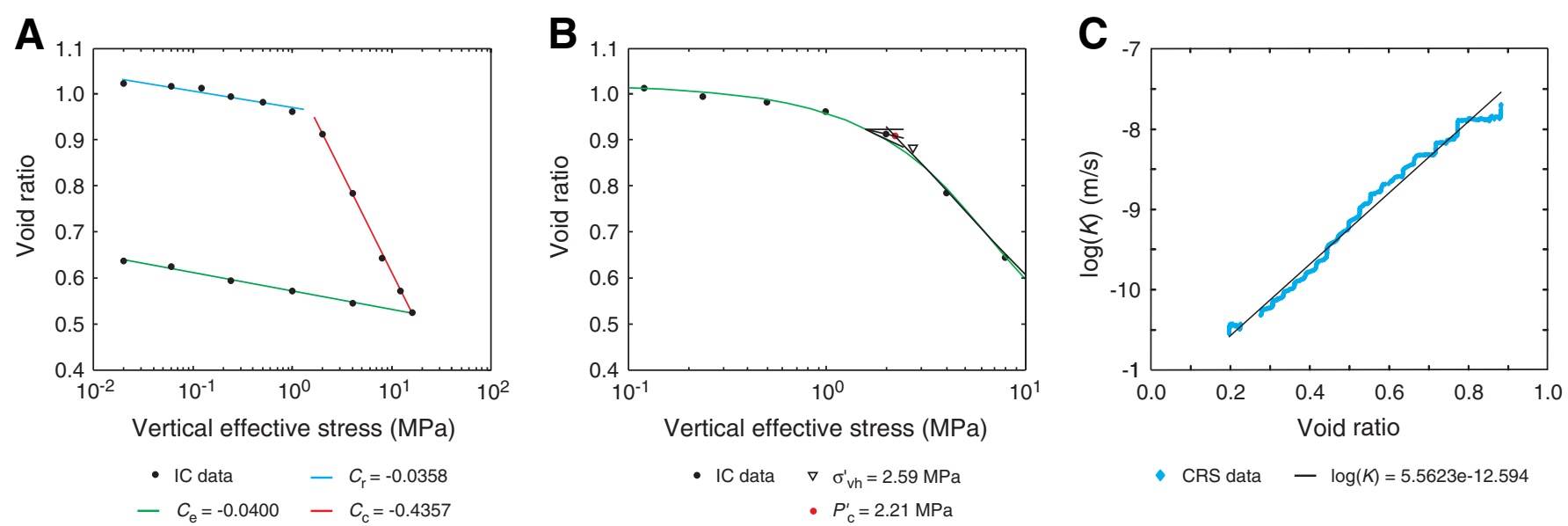
Figure F8. Plots of experimental results from Sample 322-C0011B-28R-1, 0-17 cm (lithologic Unit III; $568 \mathrm{~m}$ CSF; silty claystone). A. Data from incremental loading consolidation test (IC) with regression lines for primary compression (red) and elastic compression (green). B. Logarithm of hydraulic conductivity as a function of void ratio determined from incremental loading consolidation test. Note that this sample was remolded before testing.
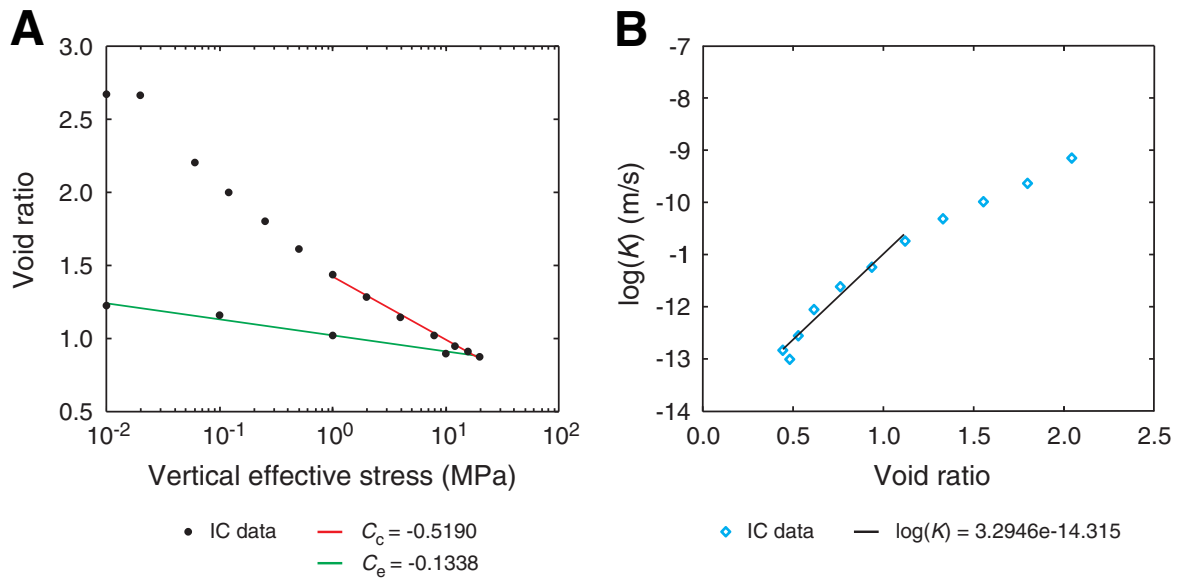
Figure F9. Plots of experimental results from Sample 322-C0011B-35R-5, 67-87 cm (lithologic Unit III; 629.57 m CSF; silty claystone). A. Data from incremental loading consolidation test (IC) conducted on intact sample with regression lines for recompression (blue), primary compression (red), and elastic compression (green). B. Maximum past effective stress $P^{\prime}{ }_{c}$ with Casagrande construction and in situ hydrostatic vertical effective stress $\sigma_{v h}^{\prime}$. C. Logarithm of hydraulic conductivity as a function of void ratio determined from IC.
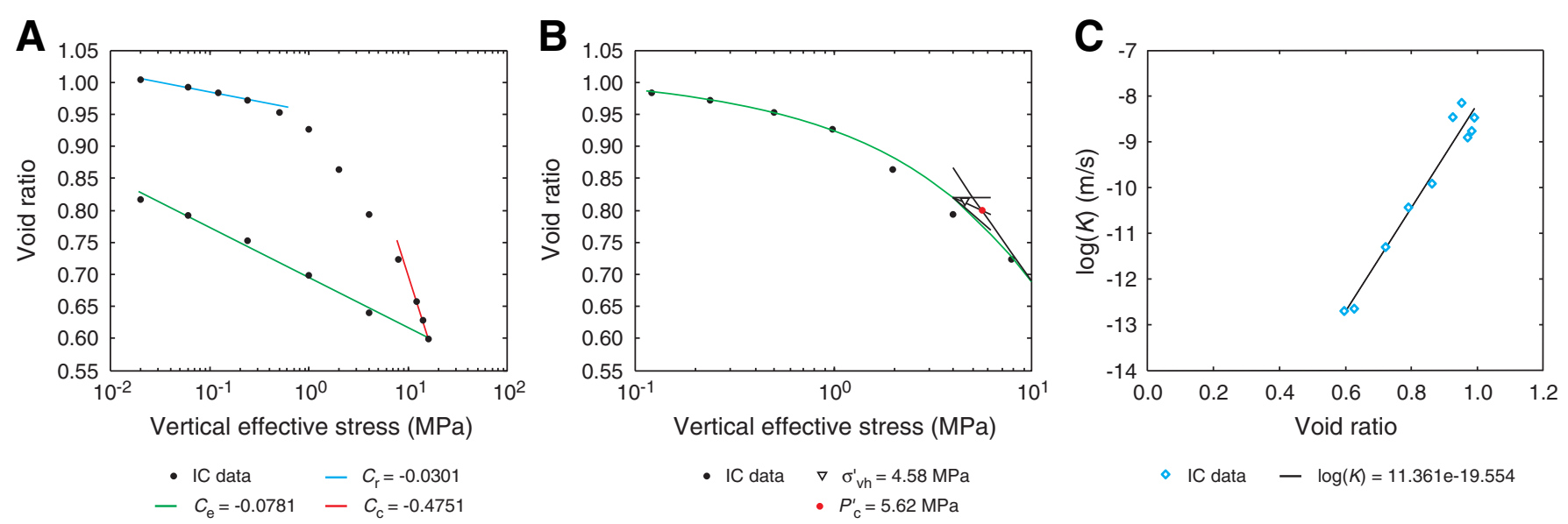
Figure F10. Plots of experimental results from Sample 322-C0011B-51R-2, 48-58 cm (lithologic Unit IV; 749.375 m CSF; silty claystone). A. Data from incremental loading consolidation test (IC) conducted on intact sample with regression lines for recompression (blue), primary compression (red), and elastic compression (green). B. Maximum past effective stress $P^{\prime}{ }_{\mathrm{c}}$ with Casagrande construction and in situ hydrostatic vertical effective stress $\sigma^{\prime}{ }_{\mathrm{vh}}$. C. Logarithm of hydraulic conductivity as a function of void ratio determined from IC.
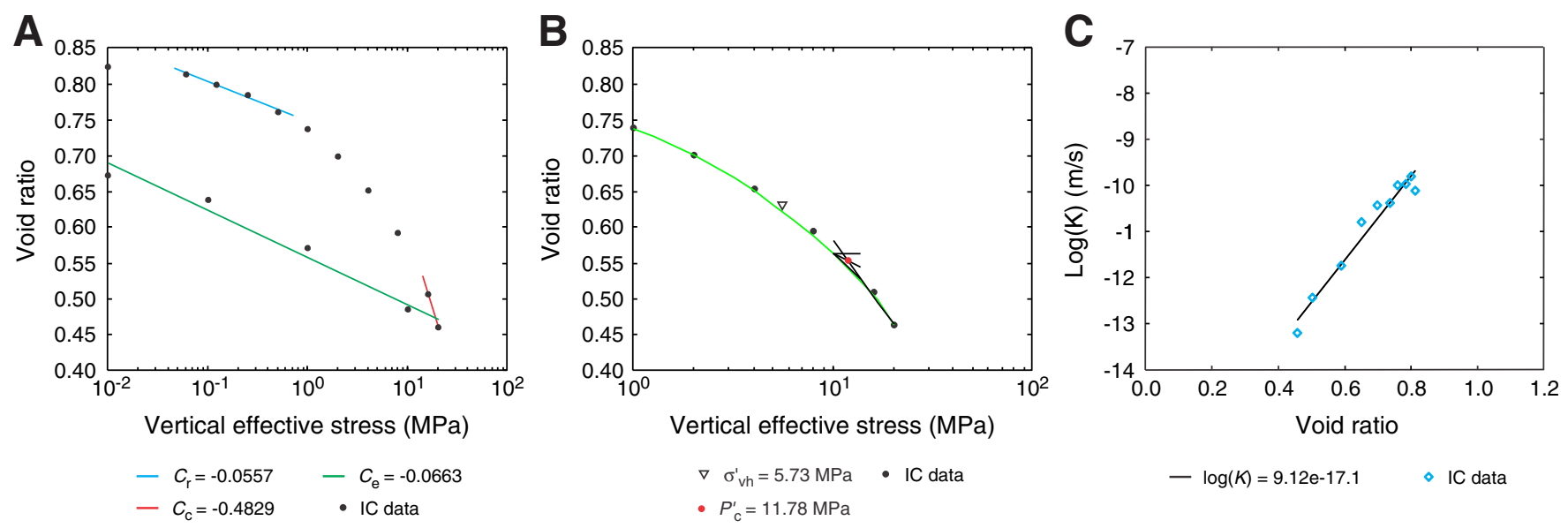

$\nabla \sigma_{\mathrm{vh}}^{\prime}=5.73 \mathrm{MPa}$

$-\log (K)=9.12 \mathrm{e}-17.1$

- IC data 
Figure F11. Plots of experimental results from Sample 322-C0011B-55R-3, 31-38 cm (lithologic Unit IV; 780.41 $\mathrm{m}$ CSF; silty sandstone). A. Data from incremental loading consolidation test (IC) conducted on intact sample with regression lines for recompression (blue), primary compression (red), and elastic compression (green). B. Maximum past effective stress $P^{\prime}{ }_{c}$ with Casagrande construction and in situ hydrostatic vertical effective stress $\sigma_{\text {vh. }}^{\prime}$. C. Logarithm of hydraulic conductivity as a function of void ratio determined from constant rate of strain consolidation test (CRS) conducted on remolded sample.
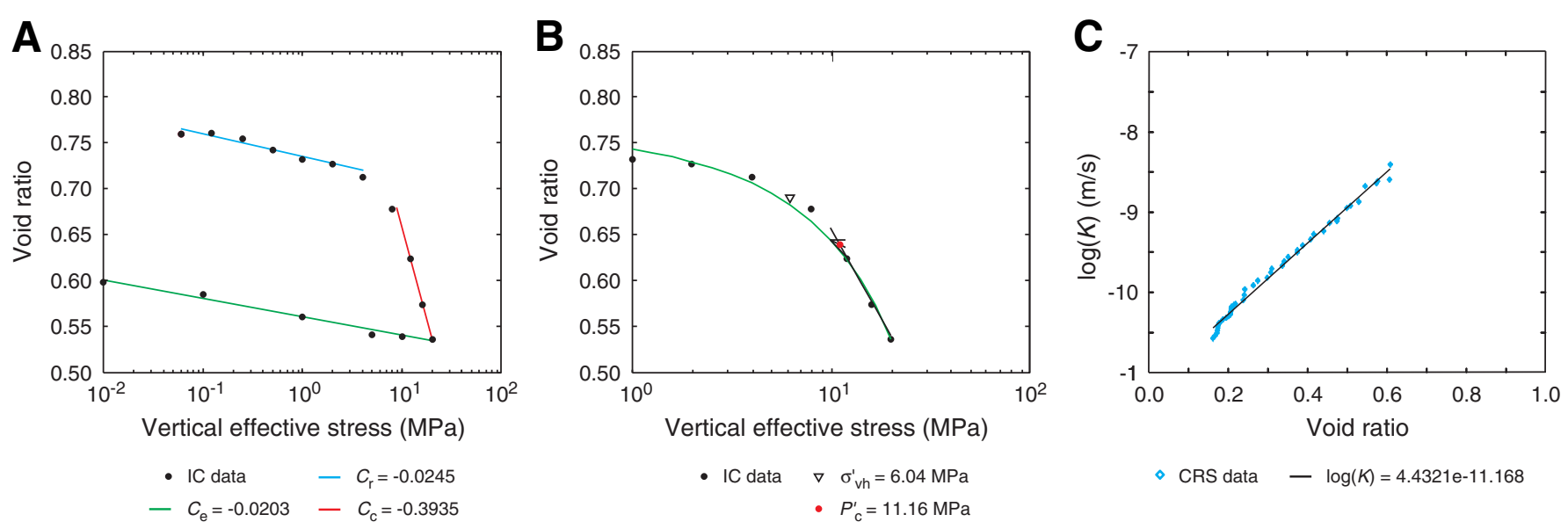
Figure F12. Plots of experimental results from Sample 322-C0011B-55R-5, 65-75 cm (lithologic Unit IV; 782.27 $\mathrm{m}$ CSF; silty sandstone). A. Data from incremental loading consolidation test (IC) conducted on intact sample with regression lines for recompression (blue), primary compression (red), and elastic compression (green). B. Maximum past effective stress $P^{\prime}{ }_{c}$ with Casagrande construction and in situ hydrostatic vertical effective stress $\sigma_{\mathrm{vh}}^{\prime}$. C. Logarithm of hydraulic conductivity as a function of void ratio determined from constant rate of strain consolidation test (CRS) conducted on remolded sample.
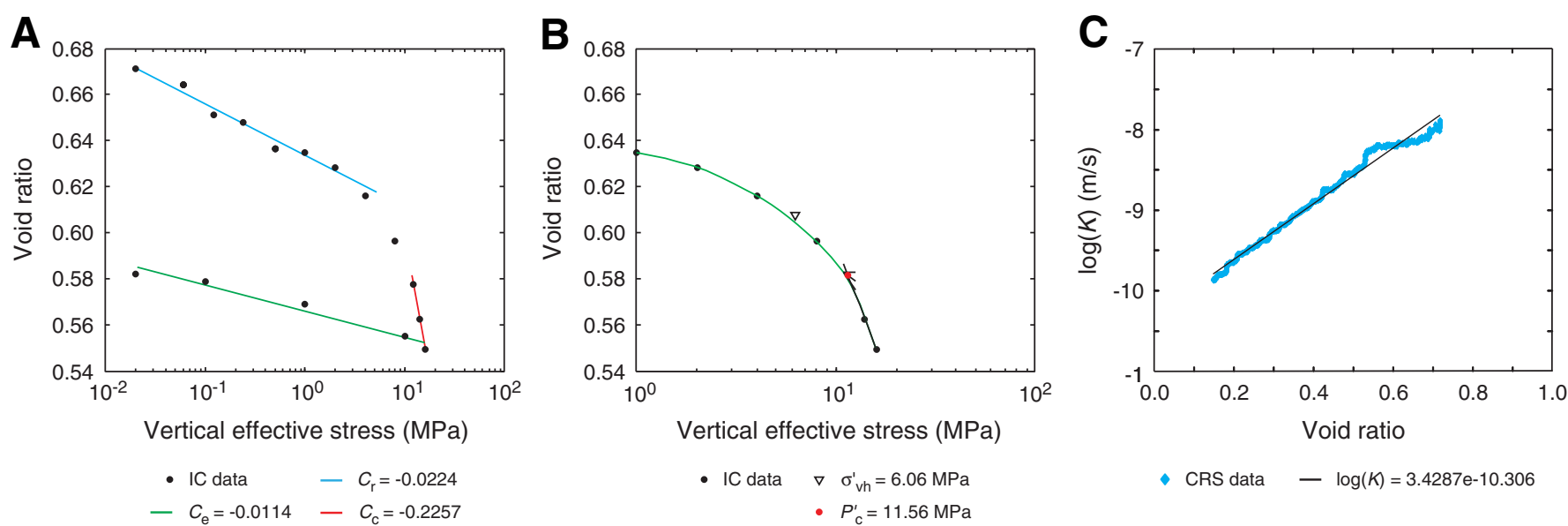

$\begin{array}{ll}- & -C_{r}=-0.0224 \\ -C_{e}=-0.0114-C_{c}=-0.2257\end{array}$ 
Figure F13. Plots of experimental results from Sample 322-C0012A-41R-2, 0-18 cm (lithologic Unit V; 424.28 m CSF; silty claystone). A. Data from incremental loading consolidation test (IC) conducted on intact sample with regression lines for recompression (blue), primary compression (red), and elastic compression (green). B. Maximum past effective stress $P^{\prime}{ }_{c}$ with Casagrande construction and in situ hydrostatic vertical effective stress $\sigma_{v h}^{\prime}$. C. Logarithm of hydraulic conductivity as a function of void ratio determined from IC.
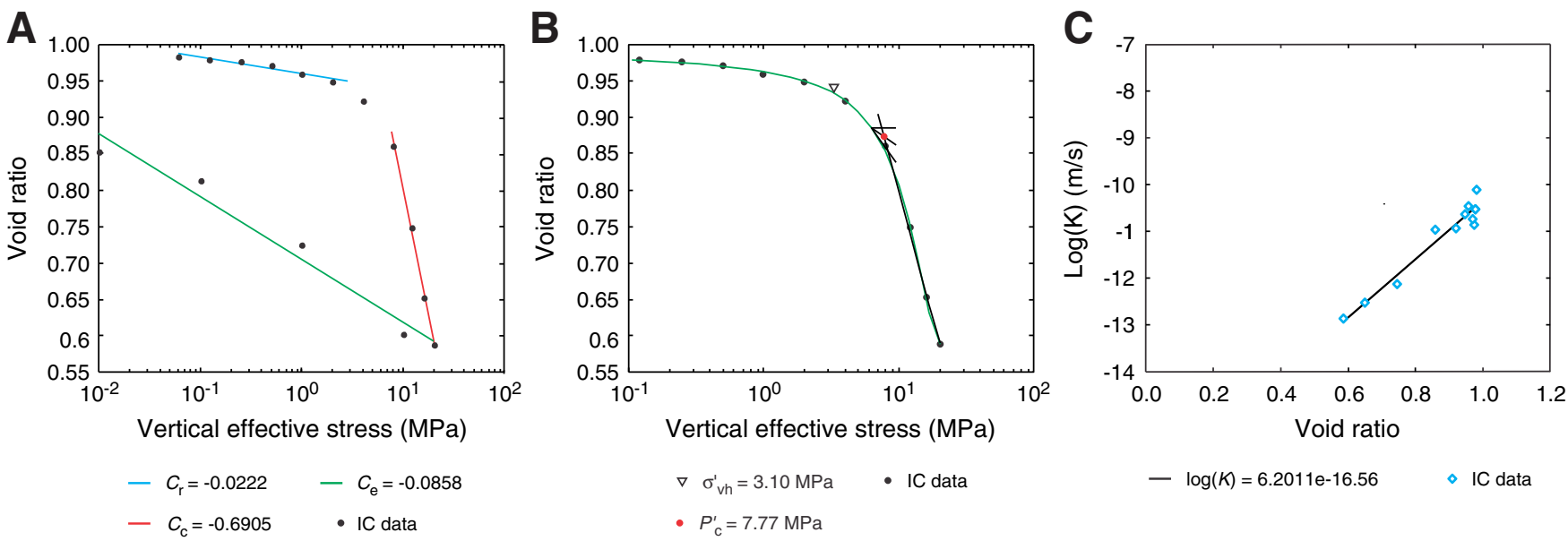
Figure F14. Plots of experimental results from Sample 322-C0012A-45R-4, 79-81 cm (lithologic Unit V; 465.58 m CSF; sandstone). A. Data from incremental loading consolidation test (IC) conducted on intact sample with regression lines for recompression (blue), primary compression (red), and elastic compression (green). B. Maximum past effective stress $P^{\prime}{ }_{c}$ with Casagrande construction and in situ hydrostatic vertical effective stress $\sigma_{\text {vh. }}^{\prime}$. C. Logarithm of hydraulic conductivity as a function of void ratio determined from constant rate of strain consolidation test (CRS) conducted on remolded sample.

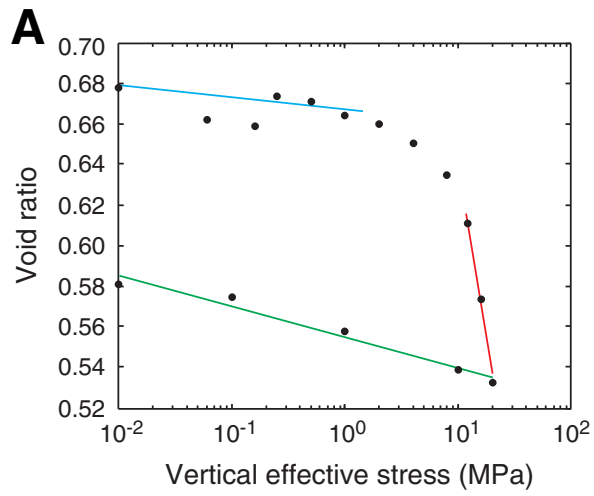

$\begin{array}{ll}\text { - IC data } & -C_{\mathrm{r}}=-0.0058 \\ -C_{\mathrm{e}}=-0.0153-C_{\mathrm{C}}=-0.3510\end{array}$
B

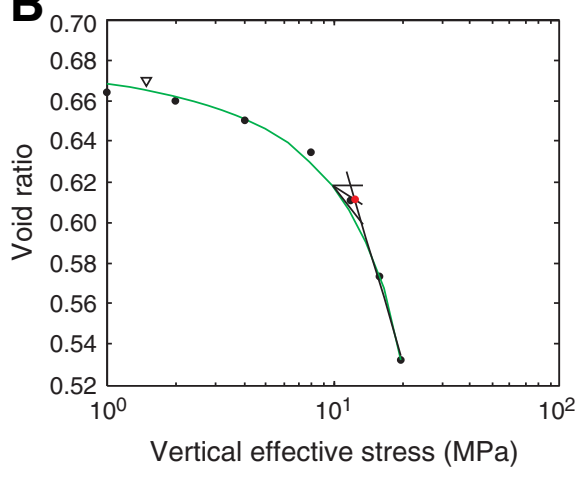

- IC data $\quad \nabla \quad \sigma_{\mathrm{vh}}^{\prime}=3.49 \mathrm{MPa}$

- $P_{\mathrm{C}}^{\prime}=12.61 \mathrm{MPa}$

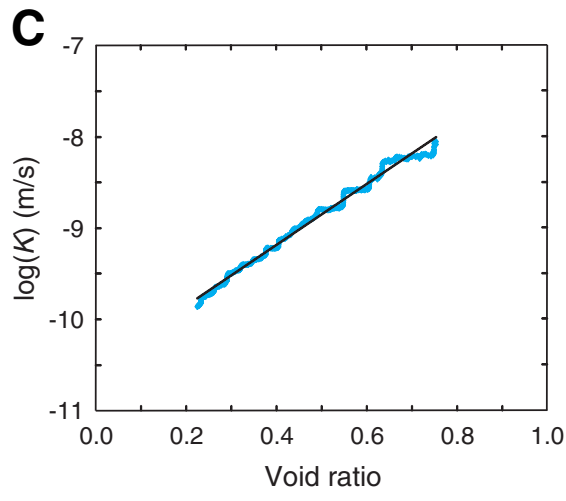

- CRS data $-\log (K)=3.3322 \mathrm{e}-10.594$ 
Figure F15. Summary plots of consolidation data showing (A) in situ intrinsic permeability, (B) compression indexes for primary consolidation, and (C) overconsolidation ratio (OCR).

A In situ intrinsic permeability $\left(\mathrm{m}^{2}\right)$

B Compression index $C_{\mathrm{c}}$

C OCR

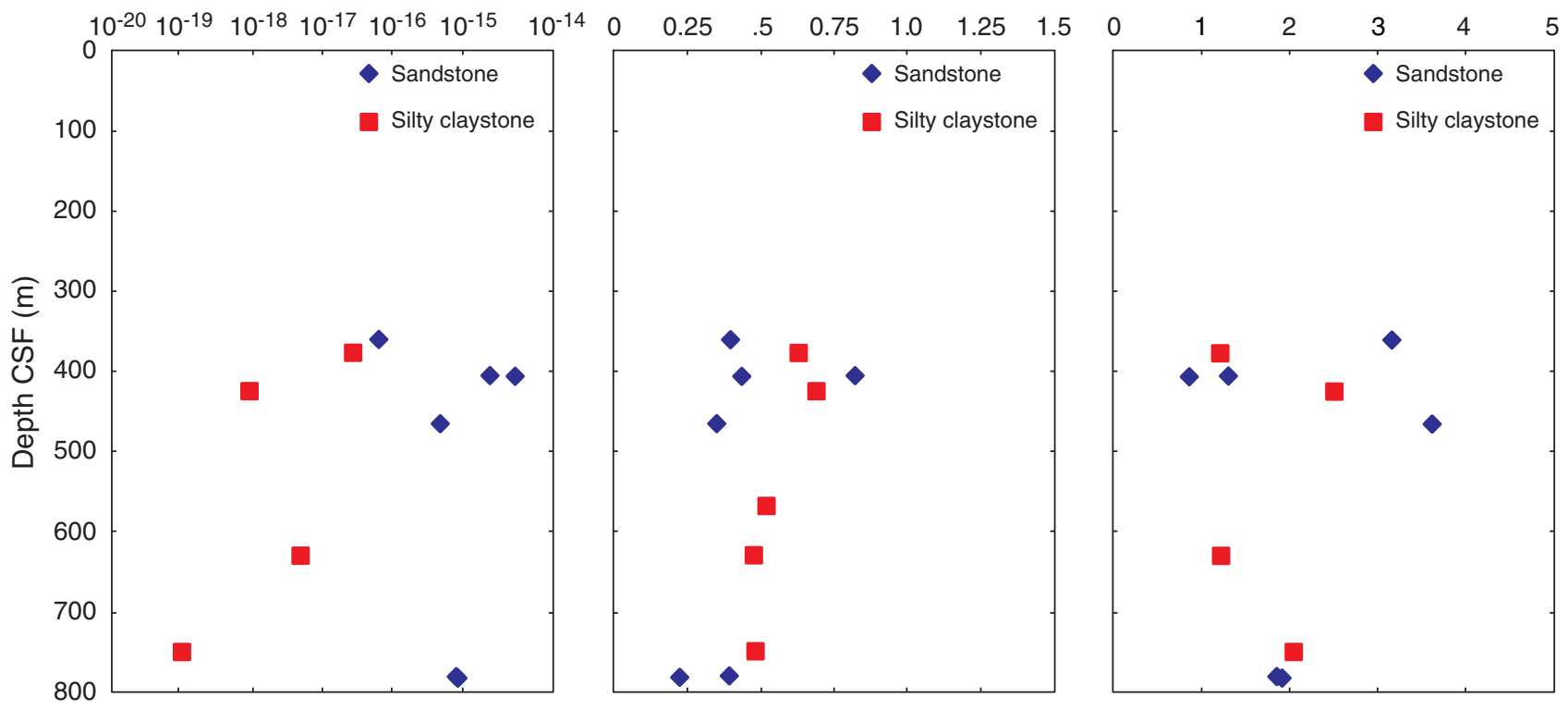


Table T1. Overview of tested samples, Sites C0011 and C0012.

\begin{tabular}{|c|c|c|c|c|c|}
\hline $\begin{array}{l}\text { Core, section, } \\
\text { interval }(\mathrm{cm})\end{array}$ & Sampling & $\begin{array}{c}\text { Conducted } \\
\text { tests }\end{array}$ & $\begin{array}{l}\text { Lithologic } \\
\text { unit }\end{array}$ & Lithology & $\begin{array}{c}\text { Depth CSF } \\
(\mathrm{m})\end{array}$ \\
\hline \multicolumn{6}{|l|}{ 322-C0011B- } \\
\hline $3 R-3,53-63$ & HR & IC, CRS & II & Tuffaceous sandstone & 360.71 \\
\hline $5 R-4,85-105$ & WR & IC & II & Silty clay & 377.81 \\
\hline $8 R-3,104-115$ & HR & IC, CRS & II & Volcanic sandstone & 405.63 \\
\hline $8 R-4,49-61$ & $\mathrm{HR}$ & IC, CRS & II & Volcanic sandstone & 406.49 \\
\hline $28 \mathrm{R}-1,0-17$ & WR & IC & III & Silty clay & 568.00 \\
\hline $35 R-5,67-87$ & WR & IC & III & Silty clay & 629.57 \\
\hline $51 R-2,48-58$ & WR & IC & IV & Silty clay & 749.38 \\
\hline $55 R-3,31-38$ & $\mathrm{HR}$ & IC, CRS & IV & Silty sandstone & 780.41 \\
\hline $55 R-5,65-75$ & HR & IC, CRS & IV & Silty sandstone & 782.27 \\
\hline \multicolumn{6}{|l|}{ 322-C0012A- } \\
\hline $41 \mathrm{R}-2,0-18$ & WR & IC & V & Silty clay & 424.88 \\
\hline 45R-4, 79-95 & WR & IC, CRS & V & Sandstone & 465.58 \\
\hline
\end{tabular}

$H R=$ half round, $W R=$ whole round. $I C=$ incremental loading,$C R S=$ constant rate of strain.

Table T2. Overview of fitted compression indexes, Sites C0011 and C0012.

\begin{tabular}{|c|c|c|c|}
\hline $\begin{array}{l}\text { Core, section, } \\
\text { interval }(\mathrm{cm})\end{array}$ & $C_{\mathrm{r}}$ fit & $C_{c}$ fit & $C_{\mathrm{e}}$ fit \\
\hline \multicolumn{4}{|l|}{ 322-C0011B- } \\
\hline $3 R-3,53-63$ & $e=0.8461+(-0.0081) \times \log \left(\sigma_{\mathrm{v}}^{\prime}\right), R^{2}=0.92$ & $e=1.1200+(-0.3977) \times \log \left(\sigma_{v}^{\prime}\right), R^{2}=1.00$ & $e=0.6618+(-0.0171) \times \log \left(\sigma_{v}^{\prime}\right), R^{2}=97$ \\
\hline $5 R-4,85-105$ & $e=1.115+(-0.0487) \times \log \left(\sigma_{v}^{\prime}\right), R^{2}=0.93$ & $e=1.2730+(-0.6294) \times \log \left(\sigma_{v}^{\prime}\right), R^{2}=0.99$ & $e=0.5900+(-0.0910) \times \log \left(\sigma_{v}^{\prime}\right), R^{2}=0.97$ \\
\hline $8 R-3,104-115$ & $e=1.585+(-0.0318) \times \log \left(\sigma_{\mathrm{v}}^{\prime}\right), R^{2}=0.73$ & $e=1.899+(-0.8193) \times \log \left(\sigma_{v}^{\prime}\right), R^{2}=1.00$ & $e=0.9215+(-0.0721) \times \log \left(\sigma_{v}^{\prime}\right), R^{2}=97$ \\
\hline $8 \mathrm{R}-4,49-61$ & $e=0.9724+(-0.0358) \times \log \left(\sigma_{v}^{\prime}\right), R^{2}=0.90$ & $e=1.045+(-0.4357) \times \log \left(\sigma_{\gamma}^{\prime}\right), R^{2}=1.00$ & $e=0.5725+(-0.0400) \times \log \left(\sigma_{v}^{\prime}\right), R^{2}=1$ \\
\hline $28 \mathrm{R}-1,0-17$ & - & $e=1.1000+(-0.5190) \times \log \left(\sigma_{v}^{\prime}\right), R^{2}=1.00$ & $e=0.6172+(-0.1338) \times \log \left(\sigma_{v}^{\prime}\right), R^{2}=0.99$ \\
\hline $35 \mathrm{R}-5,67-87$ & $e=0.9543+(-0.0301) \times \log \left(\sigma^{\prime}\right), R^{2}=0.99$ & $e=1.171+(-0.4751) \times \log \left(\sigma_{v}^{\prime}\right), R^{2}=1.00$ & $e=0.6939+(-0.0781) \times \log \left(\sigma_{v}^{\prime}\right), R^{2}=0.99$ \\
\hline $51 \mathrm{R}-2,48-58$ & $e=0.7474+(-0.0557) \times \log \left(\sigma_{v}^{\prime}\right), R^{2}=0.98$ & $e=1.089+(-0.4829) \times \log \left(\sigma_{\mathrm{v}}^{\prime}\right), R^{2}=1.00$ & $e=0.5568+(-0.0663) \times \log \left(\sigma_{v}^{\prime}\right), R^{2}=97$ \\
\hline $55 R-3,31-38$ & $e=0.7345+(-0.0245) \times \log \left(\sigma_{v}^{\prime}\right), R^{2}=0.93$ & $e=1.048+(-0.3935) \times \log \left(\sigma_{v}^{\prime}\right), R^{2}=1.00$ & $e=0.5595+(-0.0203) \times \log \left(\sigma_{v}^{\prime}\right), R^{2}=0.98$ \\
\hline $55 \mathrm{R}-5,65-75$ & $e=0.6335+(-0.0224) \times \log \left(\sigma_{v}^{\prime}\right), R^{2}=0.97$ & $e=0.8209+(-0.2257) \times \log \left(\sigma^{\prime}\right), R^{2}=1.00$ & $e=0.5657+(-0.0114) \times \log \left(\sigma_{v}^{\prime}\right), R^{2}=0.96$ \\
\hline \multicolumn{4}{|l|}{$322-\mathrm{C} 0012 \mathrm{~A}-$} \\
\hline $41 \mathrm{R}-2,0-18$ & $e=0.9585+(-0.0222) \times \log \left(\sigma_{v}^{\prime}\right), R^{2}=0.92$ & $e=1.4860+(-0.6905) \times \log \left(\sigma_{v}^{\prime}\right), R^{2}=1.00$ & $e=0.7036+(-0.0858) \times \log \left(\sigma_{\mathrm{v}}^{\prime}\right), R^{2}=97$ \\
\hline $45 R-4,79-81$ & $e=0.6671+(-0.0058) \times \log \left(\sigma_{v}^{\prime}\right), R^{2}=0.79$ & $e=0.9914+(-0.351) \times \log \left(\sigma_{v}^{\prime}\right), R^{2}=0.99$ & $e=0.5546+(-0.0153) \times \log \left(\sigma_{\mathrm{v}}^{\prime}\right), R^{2}=0.97$ \\
\hline
\end{tabular}

$C_{r}=$ recompression phase, $C_{c}=$ primary consolidation, $C_{e}=$ unloading phase $-=$ not analyzed.

Table T3. Summary of consolidation results for silty claystones, Sites C0011 and C0012.

\begin{tabular}{|c|c|c|c|c|c|c|}
\hline $\begin{array}{l}\text { Core, section, } \\
\text { interval }(\mathrm{cm})\end{array}$ & $\begin{array}{c}\sigma_{v h}^{\prime} \\
(\mathrm{MPa})\end{array}$ & $\begin{array}{c}P^{\prime}{ }^{c} \\
(\mathrm{MPa})\end{array}$ & OCR & $e_{P_{C}^{\prime}}^{\prime}$ & $e-\log (K)$ fit & $\begin{array}{c}k_{\mathrm{i}} \\
\left(\mathrm{m}^{2}\right)\end{array}$ \\
\hline \multicolumn{7}{|l|}{$322-\mathrm{C} 0011 \mathrm{~B}-$} \\
\hline $\begin{array}{l}5 \mathrm{R}-4,85-105 \\
28 \mathrm{R}-1,0-17\end{array}$ & $\begin{array}{l}2.82 \\
4.00\end{array}$ & $\begin{array}{c}2.32 \\
-\end{array}$ & $\begin{array}{l}1.22 \\
-\end{array}$ & $\begin{array}{c}1.0000 \\
-\end{array}$ & $\begin{array}{l}\log (K)=5.1012 \mathrm{e}-14.841, R^{2}=0.95 \\
\log (K)=3.2946 \mathrm{e}-14.315, R^{2}=0.96\end{array}$ & $\begin{array}{c}1.8 \times 10^{-17} \\
-\end{array}$ \\
\hline $35 \mathrm{R}-5,67-87$ & 4.58 & 5.62 & 1.23 & 0.8008 & $\log (K)=11.361 \mathrm{e}-19.554, R^{2}=0.96$ & $3.5 \times 10^{-18}$ \\
\hline $51 \mathrm{R}-2,48-58$ & 5.73 & 11.78 & 2.06 & 0.5517 & $\log (K)=9.1200 \mathrm{e}-17.100, R^{2}=0.96$ & $8.5 \times 10^{-20}$ \\
\hline $\begin{array}{r}322-\mathrm{C} 0012 \mathrm{~A}- \\
41 \mathrm{R}-2,0-18\end{array}$ & 3.10 & 7.77 & 2.51 & 0.8729 & $\log (K)=6.2011 \mathrm{e}-16.560, R^{2}=0.95$ & $7.1 \times 10^{-19}$ \\
\hline
\end{tabular}

$\sigma_{\mathrm{vh}}^{\prime}=$ in situ hydrostatic vertical effective stress, $P_{c}^{\prime}{ }_{c}=$ maximum past effective stress, $\mathrm{OCR}=$ overconsolidation ratio, $e_{\mathrm{p}}{ }_{\mathrm{c}}=$ in situ void ratio, $e$-log $(K)=$ curve fit, $k_{\mathrm{i}}=$ in situ intrinsic permeability. $-=$ no data. 
Table T4. Summary of consolidation results for sandstones, Sites C0011 and C012.

\begin{tabular}{|c|c|c|c|c|c|c|}
\hline $\begin{array}{l}\text { Core, section, } \\
\text { interval }(\mathrm{cm})\end{array}$ & $\begin{array}{l}\sigma_{v h}^{\prime} \\
(\mathrm{MPa})\end{array}$ & $\begin{array}{c}P_{c}^{\prime}{ }_{c} \\
(\mathrm{MPa})\end{array}$ & OCR & $e_{\sigma^{\prime} \vee \mathrm{h}}$ & $e-\log (K)$ fit & $\begin{array}{c}k_{\mathrm{i}} \\
\left(\mathrm{m}^{2}\right)\end{array}$ \\
\hline \multicolumn{7}{|l|}{ 322-C0011B- } \\
\hline $3 R-3,53-63$ & 2.19 & 6.91 & 3.16 & 0.7900 & $\log (K)=5.6163 \mathrm{e}-3.834, R^{2}=0.99$ & $4.0 \times 10^{-17}$ \\
\hline $8 R-3,104-115$ & 2.58 & 3.35 & 1.30 & 1.4960 & $\log (K)=3.4927 \mathrm{e}-13.104, R^{2}=0.99$ & $1.3 \times 10^{-15}$ \\
\hline $8 R-4,49-61$ & 2.59 & 2.21 & 0.85 & 0.9096 & $\log (K)=5.5623 \mathrm{e}-12.594, R^{2}=0.99$ & $2.9 \times 10^{-15}$ \\
\hline $55 R-3,31-38$ & 6.04 & 11.16 & 1.85 & 0.6383 & $\log (K)=4.4321 \mathrm{e}-11.168, R^{2}=0.99$ & $4.5 \times 10^{-16}$ \\
\hline $55 \mathrm{R}-5,65-75$ & 6.06 & 11.56 & 1.91 & 0.5800 & $\log (K)=3.4287 \mathrm{e}-10.306, R^{2}=0.99$ & $4.8 \times 10^{-16}$ \\
\hline \multicolumn{7}{|l|}{ 322-C0012A- } \\
\hline $45 R-4,79-81$ & 3.49 & 12.61 & 3.61 & 0.6111 & $\log (K)=3.3322 \mathrm{e}-10.594, R^{2}=0.99$ & $2.8 \times 10^{-16}$ \\
\hline
\end{tabular}

$\sigma_{v h}^{\prime}=$ in situ hydrostatic vertical effective stress, $P_{c}^{\prime}=$ the yield stress, OCR = overconsolidation ratio, $e_{\sigma^{\prime} v h}=$ in situ void ratio for silty claystones, $e$ $\log (K)=$ curve fit, $k_{\mathrm{i}}=$ in situ intrinsic permeability.

Table T5. Nomenclature used in consolidation studies, Expedition 322.

\begin{tabular}{|c|c|c|c|}
\hline Variable & Definition & Dimension & Unit \\
\hline$h_{\mathrm{n}}$ & Height of specimen & $\mathrm{L}$ & $\mathrm{mm}$ \\
\hline$h_{0}$ & Initial height of specimen & $\mathrm{L}$ & $\mathrm{mm}$ \\
\hline K & Hydraulic conductivity & $\mathrm{L} / \mathrm{T}$ & $\mathrm{m} / \mathrm{s}$ \\
\hline$K_{0}$ & Hydraulic conductivity at zero void ratio & $\mathrm{L} / \mathrm{T}$ & $\mathrm{m} / \mathrm{s}$ \\
\hline OCR & Overconsolidation ratio & Dimensionless & - \\
\hline$P_{c}^{\prime}$ & Maximum past effective stress & $\mathrm{M} / \mathrm{LT}^{2}$ & $\mathrm{MPa}$ \\
\hline$C_{v}$ & Coefficient of consolidation & $\mathrm{L}^{2} / \mathrm{T}$ & $\mathrm{m}^{2} / \mathrm{s}$ \\
\hline$e$ & Void ratio & Dimensionless & - \\
\hline$e_{\text {end }}$ & Final void ratio measured on specimen & Dimensionless & - \\
\hline$e_{0}$ & Void ratio at the beginning of a load step & Dimensionless & - \\
\hline$e_{\mathrm{i}}$ & Void ratio at the end of a load step & Dimensionless & - \\
\hline$e_{P^{\prime} \mathrm{C}}$ & In situ void ratio for silty claystones & Dimensionless & - \\
\hline$e_{\sigma^{\prime} v h}$ & In situ void ratio for sandstone & Dimensionless & - \\
\hline$k$ & Intrinsic permeability & $L^{2}$ & $\mathrm{~m}^{2}$ \\
\hline$k_{\mathrm{i}}$ & In situ intrinsic permeability & $\mathrm{L}^{2}$ & $\mathrm{~m}^{2}$ \\
\hline$m_{v}$ & Coefficient of volume compressibility & $\mathrm{LT}^{2} / \mathrm{M}$ & $\mathrm{m}^{2} / \mathrm{MN}$ \\
\hline$\Delta_{\mathrm{u}}$ & Excess pore pressure & $\mathrm{M} / \mathrm{LT}^{2}$ & $\mathrm{kPa}$ \\
\hline$\dot{\varepsilon}$ & Strain rate & $1 / T$ & $1 / \mathrm{s}$ \\
\hline$\gamma_{w}$ & Unit weight of water & $M / L^{2} T^{2}$ & $N / m^{3}$ \\
\hline$\sigma_{v}$ & Applied vertical stress & $\mathrm{M} / \mathrm{LT}^{2}$ & $\mathrm{MPa}$ \\
\hline$\sigma_{v}^{\prime}$ & Vertical effective stress & $\mathrm{M} / \mathrm{LT}^{2}$ & $\mathrm{MPa}$ \\
\hline$\sigma_{\mathrm{v} 0}^{\prime}$ & Vertical effective stress of current load step & $\mathrm{M} / \mathrm{LT}^{2}$ & $\mathrm{MPa}$ \\
\hline$\sigma_{\mathrm{v} 1}^{\prime}$ & Vertical effective stress of previous load step & $\mathrm{M} / \mathrm{LT}^{2}$ & $\mathrm{MPa}$ \\
\hline$\sigma_{v h}^{\prime \prime}$ & Hydrostatic vertical effective stress & $\mathrm{M} / \mathrm{LT}^{2}$ & $\mathrm{MPa}$ \\
\hline$v$ & Dynamic fluid viscosity & M/LT & Pa.s \\
\hline g & Gravitational acceleration & $\mathrm{L} / \mathrm{T}^{2}$ & $\mathrm{~m} / \mathrm{s}^{2}$ \\
\hline$C_{c}$ & Compression index of primary consolidation phase & Dimensionless & - \\
\hline$C_{\mathrm{r}}$ & Compression index of recompression phase & Dimensionless & - \\
\hline$C_{e}$ & Compression index of unloading phase & Dimensionless & - \\
\hline$V_{w}$ & Pore water volume at the end of the test & $\mathrm{V}$ & $\mathrm{cm}^{3}$ \\
\hline$V_{\mathrm{b}}$ & Bulk volume at the end of the test & $\mathrm{V}$ & $\mathrm{cm}^{3}$ \\
\hline$t$ & Testing time & $\mathrm{T}$ & s \\
\hline$\rho_{\mathrm{w}}$ & Density of pore water & $M / L^{3}$ & $\mathrm{~kg} / \mathrm{m}^{3}$ \\
\hline$\rho_{\mathrm{b}}$ & Bulk density of sediment & $M / L^{3}$ & $\mathrm{~kg} / \mathrm{m}^{3}$ \\
\hline$z$ & Depth below seafloor & $\mathrm{L}$ & $\mathrm{m}$ \\
\hline$\alpha$ & Slope of $e-\log (K)$ fit & Dimensionless & - \\
\hline
\end{tabular}

